\title{
Influence of a Commercial Biological Fungicide containing Trichoderma harzianum Rifai T-22 on Dissipation Kinetics and Degradation of Five Herbicides in Two Types of Soil
}

\author{
Ewa Szpyrka ${ }^{1, *} \mathbb{1}$, Magdalena Podbielska ${ }^{1}\left(\mathbb{D}\right.$, Aneta Zwolak ${ }^{1}$, Bartosz Piechowicz ${ }^{1}$, \\ Grzegorz Siebielec ${ }^{2}$ and Magdalena Słowik-Borowiec ${ }^{1}$ \\ 1 University of Rzeszow, Institute of Biology and Biotechnology, 1 Pigonia St., 35-310 Rzeszów, Poland; \\ magdapodbiel@gmail.com (M.P.); azwolak@ur.edu.pl (A.Z.); bpiechow@univ.rzeszow.pl (B.P.); \\ m.slowik_borowiec@interia.pl (M.S.-B.) \\ 2 The Institute of Soil Science and Plant Cultivation, Department of Soil Erosion and Land Conservation, \\ 8 Czartoryskich St., 24-100 Puławy, Poland; gs@iung.pulawy.pl \\ * Correspondence: ewaszpyrka@interia.pl; Tel./Fax: +48-17-851-68-14
}

Received: 17 February 2020; Accepted: 17 March 2020; Published: 18 March 2020

\begin{abstract}
Biological crop protection is recommended to be applied alternately or together with chemical one, to protect human health from the excessive use of toxic pesticides. Presence of microorganisms can influence the concentration of chemical pollutants in soil. The aim of this study is to estimate the influence of a commercial biological fungicide containing Trichoderma harzianum Rifai T-22 on dissipation kinetics and degradation of five herbicides belonging to different chemical classes: clomazone, fluazifop-P-butyl, metribuzin, pendimethalin, and propyzamide, in two types of soil. Results of the study revealed that T. harzianum T-22 influences pesticide degradation and dissipation kinetics of the non-persistent herbicides: clomazone, fluazifop-P-butyl, and metribuzin. In soil with a higher content of nitrogen, phosphorus, and organic matter, degradation increased by up to $24.2 \%, 24.8 \%$, and $23.5 \%$ for clomazone, fluazifop-P-butyl, and metribuzin, respectively. In soil with lower organic content, degradation was on a low level, of $16.1 \%, 17.7 \%$, and $16.3 \%$ for clomazone, fluazifop-P-butyl, and metribuzin, respectively. In our study, the addition of the biological preparation shortened herbicide dissipation half-lives, from 0.3 days (2.9\%) for fluazifop-P-butyl, to 18.4 days (25.1\%) for clomazone. During the degradation study, no significant differences were noticed for pendimethalin, belonging to persistent substances. Biological protection of crops can modify pesticide concentrations and dissipation rates. On one hand, this may result in the reduced effectiveness of herbicide treatments, while on the other, it can become a tool for achieving cleaner environment.
\end{abstract}

Keywords: herbicide; biodegradation; Trichoderma harzianum; half-life

\section{Introduction}

Pesticides are substances used worldwide, especially in the plant production, to combat weeds, pests, and diseases, and thence to increase the yield. After fulfilling their task, a majority of pesticides remain in plants, soil, and other components of the environment, and can be uptaken by a consumer, mainly with food or water [1,2].

Because of the concerns related to the environment and human health, it is recommended to use biopesticides in plant protection. Nevertheless, today biopesticides account for about $5 \%$ of the total crop protection market. The number of biopesticides registered in the European Union (EU) is lower than that in other countries, like China, India, or the United States, and this results from a complex 
registration processes [3]. In 2015, 36 microorganisms were approved for the use in pest control in the EU [4]. This small share of biological methods also results from a fact that biopesticides are usually less effective than chemical pesticides, and their application is more complicated [5].

Chemical pesticides are often persistent pollutants, accumulating in the environment. They could be degraded by physical, chemical, or photochemical processes, and also by microorganism [6]. Among biological organisms, bacteria such as Pseudomonas, Bacillus, Alcaligenes Flavobacterium, Escherichia coli, Clostridium, and Thiobacillus, are those with the highest capacity to degrade pesticides, even so persistent as dichlorodiphenyltrichloroethane (DDT). Other types of microorganism capable to decompose these xenobiotics are: Actinomycetes (Micromonospora, Actinomyces, Nocardia, Streptomyces), fungi (Rhizopus, Cladosporium, Penicillium, Aspergillus, Fusarium, Mucor, Trichoderma spp., Mortierella sp.), algae (small green algae, Chlamydomonas, a genus of diatoms), and yeast $[7,8]$.

Apart from pesticides, microfungi may transform other persistent xenobiotics: aromatic and aliphatic hydrocarbons, including polycyclic aromatic hydrocarbons, nitro aromatics, plasticizers, dibenzofurans, and biphenyls. Filamentous fungi may use two types of enzymatic systems for degradation of these substances: intracellular (cytochromes P450) and exocellular (peroxidases and laccases) [6].

Trichoderma spp. are microscopic soilborne filamentous fungi belonging to the division Ascomycota, widespread in the world and described for the first time in 1794. Fungi successfully colonize their habitats and efficiently combat their competitors [9]. Trichoderma spp. can colonize aboveground and belowground plant organs, and are present between living cells. They are used as biopesticides because of their ability to destroy other fungi and certain nematodes, induce resistance to plant pathogens, impart abiotic stress tolerance, improve plant growth and vigor, solubilize plant nutrients, and bioremediate heavy metals and environmental pollutants. Furthermore, they can produce secondary metabolites and enzymes: chitinases, $\beta$-glucanases, cellulases, and protease, which found application in industry. Nowadays, $60 \%$ of registered bio-fungicides are based on Trichoderma [10,11].

Trichoderma spp. can degrade persistent organochlorine pesticides: endrin, aldrin, and DDT [12], endosulfan [13,14], organophosphate: chlorpiryfos [15,16], fenitrothion, fenitrooxon [17], paration methyl [14], and benzimidazole, like carbendazim [18].

Currently, eight strains of Trichoderma are used in plant protection products in the EU [19]. One of them is T. harzianum Rifai strain, which is recommended against soil and foliar pathogens, including Pythium, Rhizoctonia, Fusarium, and Botrytis. Its target hosts are a wide range of crops including: vegetables (tomato, cucumber, and lettuce), ornamentals, soybean, rice, sugarcane, and maize. T. harzianum Rifai T-22 develops well in various environmental conditions, in a wide temperature range $\left(8-34^{\circ} \mathrm{C}\right)$, $\mathrm{pH}$ of $4-8.5$, on various types of substrates and roots of many plant species [20,21].

Nowadays, increasingly more emphasis is being placed on the use of biological agents in the plant cultivation, either combined with or instead of toxic chemical pesticides. In the integrated crop protection, biological control is recommended with or instead of chemical control. Such situation raises questions if applied microorganisms can change the concentration of chemical pesticides. This paper presents the influence of a new commercial biological fungicide containing T. harzianum Rifai T-22 on dissipation kinetics and degradation of five herbicides currently approved for the use in the EU, which are highly toxic to humans: clomazone, fluazifop-P-butyl, metribuzin, pendimethalin, and propyzamide (Table 1). These biological and chemical preparations are registered in Poland for protection of certain vegetables: lettuce, tomatoes, and cucumbers [22]. In literature, no information is available on the influence of that fungal strain on the fate of those chemical substances in soil. 
Table 1. Active substances of studied herbicides and their properties [23,24].

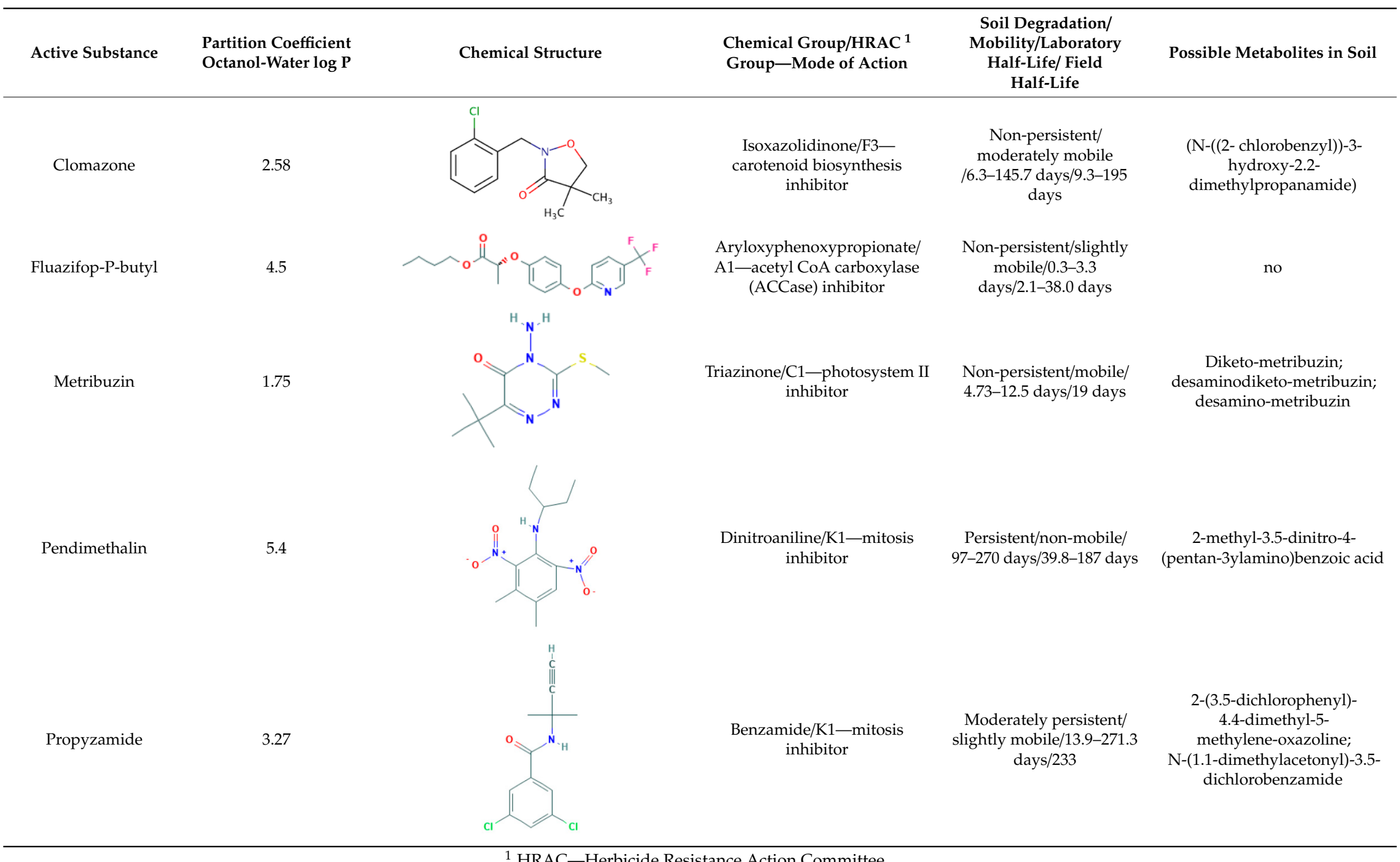




\section{Results}

Dissipation parameters (kinetic equations with correlation coefficients and half-lives, $\mathrm{t}_{\frac{1}{2}}$ ) of five tested herbicides in two types of soil without and with T. harzianum Rifai T-22 added are presented in Table 2. Experiment 1 was conducted in soil 1 and experiment 2 was conducted in soil 2.

In experiment 1 , the initial values found for the herbicides were higher, and this can be associated with soil 1 properties and higher sorption of pesticides. Soil 1 has higher organic content (humus content of $69.9 \pm 0.5 \%$, vs. $55.6 \pm 0.4 \%$ in soil 2$)$ and smaller particles (0-5 mm, vs. $0-30 \mathrm{~mm}$ in soil 2) (Table 3). Pesticide dissipation was described by exponential equations of (pseudo) first-order kinetics, in which the initial concentration does not affect the half-life $[25,26]$. 
Table 2. Dissipation parameters of herbicides in soil without and with T. harzianum Rifai T-22 added, and differences in their half-lives between soils with and without fungi.

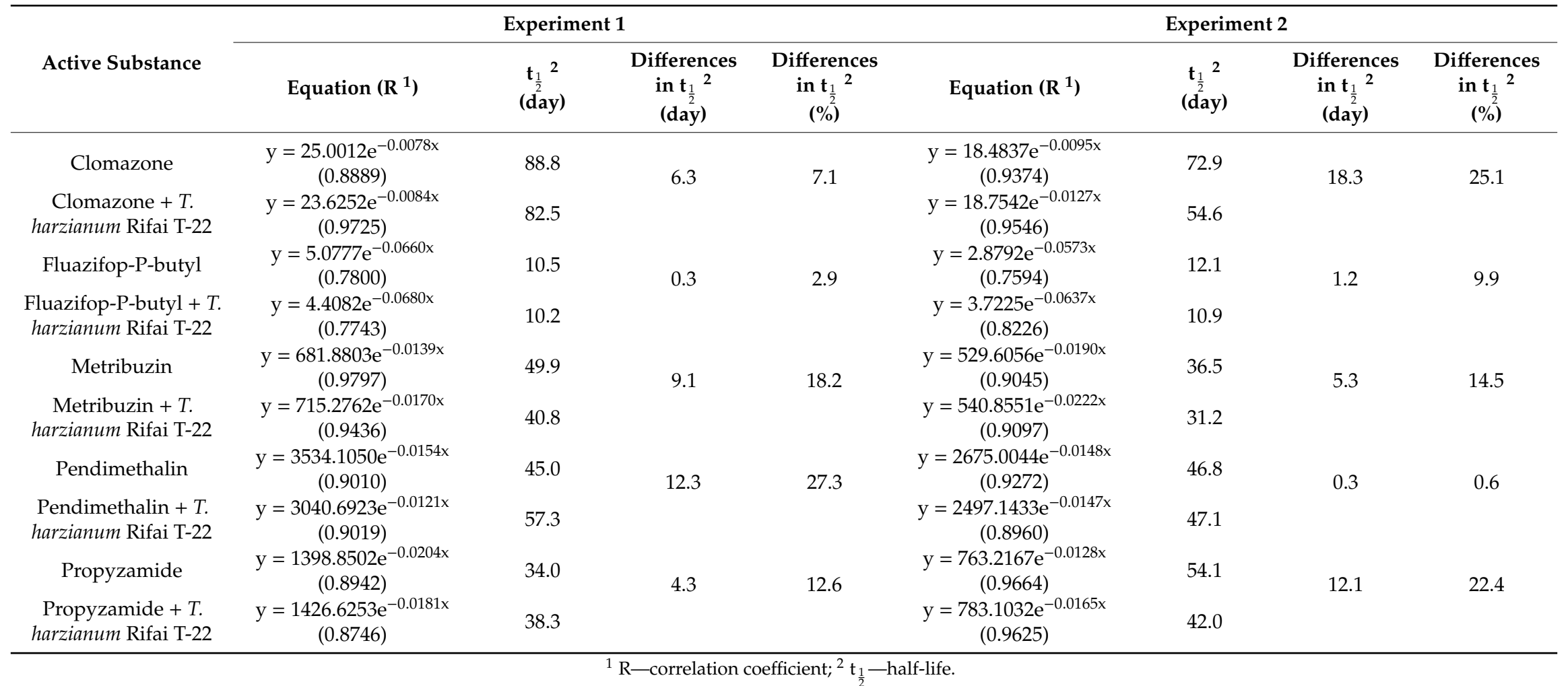


Table 3. Soils parameters.

\begin{tabular}{|c|c|c|}
\hline Parameter & Soil 1 & Soil 2 \\
\hline Type & $\begin{array}{l}\text { Horticultural soil recommended for vegetable } \\
\text { production }\end{array}$ & $\begin{array}{c}\text { Universal peat substrate mixed with } \\
\text { perlite }\end{array}$ \\
\hline Fraction & $0-5 \mathrm{~mm}$ & $0-30 \mathrm{~mm}$ \\
\hline $\mathrm{pH}$ & $4.6 \pm 0.1^{1}$ & $5.3 \pm 0.1$ \\
\hline Humus content & $69.9 \pm 0.5 \%$ & $55.6 \pm 0.4 \%$ \\
\hline Total carbon & $46.4 \pm 0.4 \%$ & $36.6 \pm 0.3 \%$ \\
\hline Organic carbon & $40.5 \pm 0.4 \%$ & $32.2 \pm 0.4 \%$ \\
\hline Total nitrogen & $1.6 \pm 0.1 \%$ & $1.4 \pm 0.1 \%$ \\
\hline $\begin{array}{l}\text { Assimilable } \\
\text { phosphorus }\end{array}$ & $104.5 \pm 2.2 \mathrm{mg} \mathrm{P}_{2} \mathrm{O}_{5} / 100 \mathrm{~g}$ & $14.9 \pm 0.6 \mathrm{mg} \mathrm{P} \mathrm{P}_{5} / 100 \mathrm{~g}$ \\
\hline $\begin{array}{l}\text { Other elements, as } \\
\mathrm{mg} / \mathrm{kg}\end{array}$ & $\begin{array}{c}\text { Li } 0.13 \pm 0.01, \text { Be } 0.03 \pm 0.01, \mathrm{~V} 1.71 \pm 0.30, \mathrm{Cr} \\
1.32 \pm 0.30, \mathrm{Mn} 25.07 \pm 1.80, \mathrm{Co} 0.20 \pm 0.02, \mathrm{Ni} \\
1.09 \pm 0.09, \mathrm{Cu} 9.47 \pm 1.10, \mathrm{Zn} 12.16 \pm 2.60, \mathrm{As} \\
1.37 \pm 0.10, \mathrm{Se} 0.52 \pm 0.08, \mathrm{Sr} 33.83 \pm 4.20, \mathrm{Mo} \\
11.57 \pm 1.90, \mathrm{Cd} 0.15 \pm 0.04, \mathrm{Sb} 0.06 \pm 0.02, \mathrm{Ba} \\
29.62 \pm 2.90, \mathrm{La} 0.59 \pm 0.12, \mathrm{Ce} 1.42 \pm 0.30, \mathrm{Eu} \\
0.03 \pm 0.01, \mathrm{Gd} 0.14 \pm 0.02, \mathrm{Tl} 0.02 \pm 0.01, \mathrm{~Pb} \\
5.06 \pm 0.80, \mathrm{Bi} 0.08 \pm 0.01, \mathrm{Na} 173.50 \pm 8.90, \\
\mathrm{Mg} 805.79 \pm 19.60, \mathrm{Al} 699.63 \pm 42.0, \mathrm{~K} 1080.42 \\
\pm 25.0, \mathrm{Ca} 14390.90 \pm 256.0, \mathrm{Fe} 2808.49 \pm 86.0\end{array}$ & $\begin{array}{c}\mathrm{Li} 0.48 \pm 0.09, \mathrm{Be} 0.07 \pm 0.02, \mathrm{~V} 3.26 \pm \\
0.15, \mathrm{Cr} 1.95 \pm 0.17, \mathrm{Mn} 30.74 \pm 1.16, \mathrm{Co} \\
0.93 \pm 0.06, \mathrm{Ni} 4.30 \pm 0.13, \mathrm{Cu} 3.78 \pm 0.41 \\
\mathrm{Zn} 6.75 \pm 0.90, \mathrm{As} 2.66 \pm 0.11, \mathrm{Se} 0.51 \pm \\
0.02, \mathrm{Sr} 85.10 \pm 2.10, \mathrm{Mo} 0.62 \pm 0.02, \mathrm{Cd} \\
0.14 \pm 0.03, \mathrm{Sb} 0.12 \pm 0.02, \mathrm{Ba} 20.47 \pm \\
1.10, \mathrm{La} 1.49 \pm 0.08, \mathrm{Ce} 2.97 \pm 0.50, \mathrm{Eu} \\
0.06 \pm 0.02, \mathrm{Gd} 0.30 \pm 0.08, \mathrm{Tl} 0.02 \pm 0.01 \\
\mathrm{~Pb} 4.62 \pm 0.70, \mathrm{Bi} 0.10 \pm 0.03, \mathrm{Na} 299.17 \\
\pm 9.20, \mathrm{Mg} 637.42 \pm 14.10, \mathrm{Al} 1410.11 \pm \\
65.0, \mathrm{~K} 431.25 \pm 11.20, \mathrm{Ca} 22094.49 \pm \\
131.0, \mathrm{Fe} 3290.40 \pm 47.0\end{array}$ \\
\hline
\end{tabular}

${ }^{1}$ Standard deviation—SD (three replications of each sample were analyzed).

\subsection{Clomazone}

Clomazone belongs to the isoxazolidinones, from Group F3 (carotenoid biosynthesis inhibitors) according to the Herbicide Resistance Action Committee (HRAC). It is a non-persistent herbicide, moderately mobile in soil (Table 1) [24].

In experiment 1 , clomazone dissipated according to equations: $y=25.0012 \mathrm{e}^{-0.0078 \mathrm{x}}(0.8889)$ and $y=23.6252 \mathrm{e}^{-0.0084 x}(0.9725)$, and half-lives of its active substances were 88.8 and 82.5 days in soil without and with T. harzianum Rifai T-22 added, respectively (Table 2). In the soil with the fungi added, levels of clomazone residues were lower than in control samples, ranging from $0.2 \%$ on day 29 to $24.2 \%$ on day 1 . In experiment 1 , the statistically significant value $\left.p<0.01{ }^{* *}\right)$ was found only on day 64 (Figure S1a, Supplementary material).

In experiment 2, clomazone dissipated according to equations: $y=18.4837 \mathrm{e}^{-0.0095 x}(0.9374)$ and $\mathrm{y}=18.7542 \mathrm{e}^{-0.0127 \mathrm{x}}(0.9546)$, and half-lives of its active substances were 72.9 and 54.6 days in soil without and with T. harzianum Rifai T-22 added, respectively (Table 2). The highest degradation of clomazone residues was noted on day 64 of the experiment, reaching a level of $16.1 \%$. In experiment 2 , the statistically significant values $p<0.05\left(^{*}\right)$ were seen on day 29 and day 64 (Figure S1b, Supplementary material).

Observed differences in clomazone concentrations in control samples versus samples containing Trichoderma were higher in experiment 1 (a maximum of 24.2\%) than in experiment 2 (a maximum of $16.1 \%)$, in the soil containing organic matter, which has a positive influence on the degradation rate [27]. A faster clomazone dissipation rate (lower $t_{\frac{1}{2}}$ values), however, was observed in soil 2 (Table 2), and this could be associated with larger particles (0-30 mm fraction), lower organic matter content, and lower pesticide sorption, improving its bioavailability [27,28].

For clomazone a typical laboratory half-life at $20^{\circ} \mathrm{C}$ is 22.6 days (6.3-145.7 days) and its field half-life is 27.3 days (9.3-195 days) [24]. This wide spread in half-life values suggests that clomazone dissipation may be influenced by many factors, including UV irradiation [29], and the presence of oxygen [30] or ammonia-oxidizing bacteria [31]. In our study, the addition of the biological preparation shortened the dissipation half-lives by 6.3 days $(7.1 \%)$ (experiment 1 ) and 18.4 days (25.1\%) (experiment 2). Reis et al. [32] studied herbicide impact on strains of Trichoderma spp. They found that clomazone 
can reduce mycelia growth by up to $30 \%$ for some isolates, but for others it had stimulatory effect on fungi sporulation.

\subsection{Fluazifop-P-butyl}

Fluazifop-P-butyl belongs to aryloxyphenoxypropionates, from HRAC Group A1 (acetyl CoA carboxylase (ACCase) inhibitors). It is non-persistent and slightly mobile in soil (Table 1) [24].

In experiment 1 , fluazifop-P-butyl dissipated according to equations: $y=5.0777 \mathrm{e}^{-0.0660 \mathrm{x}}(0.7800)$ and $y=4.4082 \mathrm{e}^{-0.0680 \mathrm{x}}(0.7743)$, and half-lives of its active substances were 10.5 and 10.2 days in soil without and with T. harzianum Rifai T-22 added, respectively (Table 2). In soil with fungi added, fluazifop-P-butyl residues were at a lower level compared to control samples, in the range of 1.3-24.8\%. In experiment 1 , the statistically significant values $p<0.05\left(^{*}\right)$ were found on days $8,15,29$, and 43 (Figure S2a, Supplementary material).

In experiment 2, fluazifop-P-butyl dissipated according to equations: $y=2.8792 \mathrm{e}^{-0.0573 x}(0.7594)$ and $y=3.7225 \mathrm{e}^{-0.0637 x}(0.8226)$, and half-lives of its active substances were 12.1 and 10.9 days, in soil without and with T. harzianum Rifai T-22 added, respectively (Table 2). During the first month, higher levels of this herbicide were found in soil with Trichoderma, and this can be associated with soil acidification by fungi and an increase in fluazifop-P-butyl stability [33]. During the second month of the experiment, degradation of fluazifop-P-butyl residues was determined to be at a level of up to $17.7 \%$. In experiment 2 , the statistically significant value $p<0.01\left({ }^{*}\right)$ was observed on day 8 , and values with $p<0.05{ }^{* *}$ ) were found on day 15 and 43 (Figure S2b, Supplementary material).

Similarly as in the case of clomazone, observed differences in the fluazifop-P-butyl concentrations in control samples versus samples containing Trichoderma were greater in experiment 1 (a maximum of $24.8 \%$ ) than in experiment 2 (a maximum of $17.7 \%$ ), in the soil containing organic matter, which has a positive influence on degradation rate [27].

A typical laboratory half-life of fluazifop-P-butyl at $20^{\circ} \mathrm{C}$ is 1.0 days (0.3-3.3 days) and its field half-life is 8.2 days (2.1-38.0 days) [24]. In our study, $\mathrm{t}_{\frac{1}{2}}$ values were very similar in all experiments, but the addition of the biological preparation shortened the dissipation half-lives by 0.3 days (2.9\%) (experiment 1 ) and 1.2 days (9.9\%) (experiment 2) (Table 2). In the fluazifop-P-butyl breakdown, $\mathrm{pH}$ and the microbial degradation seemed to predominate [24,27]. Fluazifop-P-butyl does not inhibit T. harzianum growth [34].

\subsection{Metribuzin}

Metribuzin belongs to triazinones, from HRAC Group C1 (photosystem II inhibitor). It is non-persistent and mobile in soil (Table 1) [24].

In experiment 1 , metribuzin dissipated according to equations: $y=681.8803 \mathrm{e}^{-0.0139 x}(0.9797)$ and $y=715.2762 \mathrm{e}^{-0.0170 x}(0.9436)$, and half-lives of its active substances were 49.9 and 40.8 days in soil without and with T. harzianum Rifai T-22 added, respectively (Table 2). On the first sampling day, the metribuzin concentration was higher by $23.7 \%$ in soil with fungi versus the control samples, and then it was reduced by up to $23.5 \%$ after 3 weeks. In experiment 1 , no statistically significant differences were found between samples with and without Trichoderma (Figure S3a, Supplementary material).

In experiment 2 , metribuzin dissipated according to equations: $y=529.6056 \mathrm{e}^{-0.0190 \mathrm{x}}(0.9045)$ and $\mathrm{y}$ $=540.8551 \mathrm{e}^{-0.022 x}(0.9097)$, and half-lives of its active substances were 36.5 and 31.2 days in soil without and with T. harzianum Rifai T-22 added, respectively (Table 2). On the first sampling day, similarly as in experiment 1 , the metribuzin concentration was higher by $10.9 \%$ in soil with fungi versus the control samples, and then it was reduced by up to $16.3 \%$ after 6 weeks. In experiment 2 , the statistically significant value $p<0.05\left(^{*}\right)$ was observed only on day 1 (Figure S3b, Supplementary material).

Similarly as in the case of clomazone and fluazifop-P-butyl, observed differences in metribuzin concentrations in control samples versus samples containing Trichoderma were greater in experiment 1 (maximum 23.5\%) than in experiment 2 (maximum 16.3\%), in the soil containing organic matter, which has a positive influence on degradation [27]. Similarly as in the case of clomazone, faster metribuzin 
dissipation rate (lower $\mathrm{t}_{\frac{1}{2}}$ values) was observed in soil 2, and this could be associated with larger particles (fraction 0-30 mm), lower organic matter content, and lower pesticide sorption, improving its bioavailability $[27,28]$. In our study, the addition of the biological preparation shortened dissipation half-lives by 9.1 days (18.2\%) (experiment 1 ) and 5.3 days (14.5\%) (experiment 2 ).

According to PPDB database, a typical laboratory half-life of metribuzin at $20{ }^{\circ} \mathrm{C}$ is 7.1 days (4.73-12.5 days) and its field half-life is 19 days [24], while according to the EFSA document [26], its laboratory half-life is in the range of 5.3-48.8 days. The temperature, bacteria present, and a $\mathrm{pH}$ value also have impact on metribuzin dissipation [35]. Metribuzin does not suppress the mycelial growth of T. harzianum [36], and fungi are able to biodegrade this herbicide [37].

\subsection{Pendimethalin}

Pendimethalin is a dinitroaniline herbicide belonging to HRAC Group K1 (mitosis inhibitor). It is a persistent and non-mobile substance (Table 1) [24].

In experiment 1 , pendimethalin dissipated according to equations: $y=3534.1050 \mathrm{e}^{-0.0154 x}(0.9010)$ and $y=3040.6923 \mathrm{e}^{-0.0121 x}(0.9019)$, and half-lives of its active substances were 45.0 and 57.3 days in soil without and with T. harzianum Rifai T-22 added, respectively (Table 2). On the first sampling day, the pendimethalin concentration in soil with fungi was lower by $21.1 \%$ versus the control samples. On subsequent sampling days, similar pendimethalin concentrations were found in control samples and samples with Trichoderma. In experiment 1 , no statistically significant differences were observed between samples with and without fungi (Figure S4a, Supplementary material).

In experiment 2, pendimethalin dissipated according to equations: $y=2675.0044 \mathrm{e}^{-0.0148 \mathrm{x}}(0.9272)$ and $y=2497.1433 \mathrm{e}^{-0.0147 x}(0.8960)$, and half-lives of its active substances were 46.8 and 47.1 days in soil without and with T. harzianum Rifai T-22 added, respectively (Table 2). On the first sampling day and on day 29 after treatment, concentrations of pendimethalin were $2.3 \%$ and $3.5 \%$ higher in soil with fungi versus the control samples, respectively, and on all other sampling days its concentrations were lower, by up to $14.7 \%$ on day 29 . In experiment 2 , no statistically significant differences were observed between samples with and without fungi (Figure S4b, Supplementary material).

A typical laboratory half-life of pendimethalin at $20^{\circ} \mathrm{C}$ is 182.3 days ( $97-270$ days), and its field half-life is 100.6 days (39.8-187 days) [24]. A typical field half-life of 44 days was reported, but noted to range from 90 to 480 days depending on the soil temperature, while moisture and biodegradation are not important environmental factors influencing future processes associated with pendimethalin. Additionally, biodegradation may be attenuated by its strong adsorption to soil particles, causing its lower bioavailability [23]. Kočárek et al. [38] studied the effect of a complex of microbial strains containing lactic acid bacteria, yeast, fungi, gram-positive actinomycetes, and photosynthetic bacteria. They did not found any significant influence on the pendimethalin half-life. Ries et al. [32] observed inhibitory effects of pendimethalin on the radial mycelial growth (even up to $66 \%$ ) of some isolates of Trichoderma which could be associated with herbicide properties-a direct interference with cell division, preventing the formation of microtubules responsible for chromosome segregation during mitosis. In our study, the addition of biological preparation extended the half-life dissipation by 12.3 days $(27.3 \%)$ (experiment 1$)$ and 0.3 day $(0.6 \%)$ (experiment 2$)$ (Table 2$)$.

\subsection{Propyzamide}

Propyzamide belongs to benzamides and HRAC Group K1 (mitosis inhibitor). It is moderately persistent and slightly mobile in soil (Table 1) [24].

In experiment 1 , propyzamide dissipated according to equations: $y=1398.8502 \mathrm{e}^{-0.0204 x}(0.8942)$ $\mathrm{y}=1426.6253 \mathrm{e}^{-0.0181 \mathrm{x}}(0.8746)$, and half-lives of its active substances were 34.0 and 38.3 days in soil without and with T. harzianum Rifai T-22 added, respectively (Table 2). Differences in propyzamide concentrations observed between the samples with fungi and the controls were in a range of $6.6-31.1 \%$ on relevant sampling dates. In experiment 1 , the statistically significant value $p<0.01\left({ }^{* *}\right)$ was found only on day 64 (Figure S5a, Supplementary material). 
In experiment 2, propyzamide dissipated according to equations: $y=763.2167 \mathrm{e}^{-0.0128 \mathrm{x}}(0.9664)$ and $y=783.1032 \mathrm{e}^{-0.0165 x}(0.9625)$, and half-lives of its active substances were 54.1 and 42.0 days in soil without and with T. harzianum Rifai T-22 added, respectively (Table 2). On first two sampling dates, propyzamide levels were $0.3 \%$ and $7.4 \%$ higher in soil with fungi versus the control samples, respectively, and on all others sampling days its concentrations were lower, by up to $23.9 \%$ on day 43 . In experiment 2 , the statistically significant value $p<0.05\left({ }^{*}\right)$ was observed only on day 43 (Figure S5b, Supplementary material).

Similarly as in the case of clomazone, fluazifop-P-butyl and metribuzin, observed differences in propyzamide concentrations in control samples versus samples containing Trichoderma added were greater found in experiment 1 (maximum 31.1\% on day 29) than in experiment 2 (maximum 23.9\%), in the soil containing organic matter which has a positive influence on degradation [27]. In contrary to clomazone, fluazifop-P-butyl and metribuzin, faster propyzamide dissipation rate (lower $\mathrm{t}_{\frac{1}{2}}$ values of) was observed in soil 1 than in soil 2 (Table 2).

A typical laboratory half-life of propyzamide at $20{ }^{\circ} \mathrm{C}$ is 50.5 days (13.9-271.3 days), and its field half-life is 233 days [24]. The persistence of propyzamide varies, depending on a soil type, climatic conditions, and decomposition; and it decomposes by photodecomposition and volatilization from soil surfaces under very hot and dry conditions [23]. The addition of mineral fertilizers to soil inhibited propyzamide degradation by decreasing its resistivity [39]. In our study, after the biological preparation was added to soil, the substance half-life was extended by 4.3 days (12.6\%) (experiment 1 ), and reduced by 12.1 days (22.4\%) (experiment 2) (Table 2). Such inconclusive data imply a need for further research into the behavior of these pesticides in soil.

During the GC-MS analysis, only active substances of all herbicides were found in soil samples, and no metabolites were found by the GC-MS technique applied in the full scan mode. It was probably due to the fact that during pesticide degradation in a highly humid (57-64\%) soil, more polar metabolites can form, which cannot be determined by the applied GC-MS technique with a nonpolar HP-5 MS column.

\section{Discussion}

Many factors can influence pesticide degradation in soil: type of soil, its content of mineral and organic matter, $\mathrm{pH}$, moisture, temperature, presence of microorganisms, and chemical structure of active substances. It is reflected in half-lives of herbicides, which can vary significantly between studies. For three out of five tested pesticide: clomazone, fluazifop-P-butyl, and metribuzin, which are non-persistent, during the study on their degradation significant differences were noted between samples with the biological preparation containing T. harzianum T-22 and the control. In soil 1, in which humus content was higher by $14 \%$ versus soil 2 , the degradation was higher by up to $24.2 \%$, $24.8 \%$, and $23.5 \%$ for clomazone, fluazifop-P-butyl, and metribuzin, respectively. In soil 2, a lower level of degradation occurred, of $16.1 \%, 17.7 \%$, and $16.3 \%$ for clomazone, fluazifop-P-butyl, and metribuzin, respectively. In our study, the addition of the biological preparation shortened herbicide dissipation half-lives, from 0.3 days (2.9\%) for fluazifop-P-butyl (experiment 1 ) to 18.4 days (25.1\%) for clomazone (experiment 2). In experiment 1, higher values were found for all herbicides, and this can be associated with greater active substance adsorption by organic matter and smaller size of the soil fraction.

Many studies concern pesticide degradation by Trichoderma spp., but the majority of them are conducted in culture media in laboratory conditions propitious for fungal growth. T. viride can degrade several organophosphorus (fenitrothion, fenitrooxon, parathion methyl), carbamate, and chlorinated hydrocarbon insecticides: DDT, endrin, aldrin [12,14,17,40]. In studies conducted by Katayama and Matsumura [13], T. harzianum, was found to degrade DDT, dieldrin, endosulfan, pentachloronitrobenzene, and pentachlorophenol, but not hexachlorocyclohexane. The authors concluded that the oxidative system is the main enzyme system responsible for pesticide degradation. Jayaraman et al. [15] stated that T. viride and T. harzianum and its consortium were able to grow in fungal culture medium in the presence of chlorpyrifos, and they demonstrated an increase in the level 
of biomass and protein production. Harish et al. [16] found that T. harzianum and Rhizopus nodosus isolated from the contaminated soil can degrade up to $70-80 \%$ of chlorpyrifos and ethion in 21 days. Sharma et al. [18] demonstrated the Trichoderma spp. degradation capacity versus carbendazim, a benzimidazole-based fungicide. After 5 days, biodegradation of this active substance reached $85 \%$ for T. harzianum, $47 \%$ for $T$. viride, and $21 \%$ for $T$. atroviride.

In our study, no significant differences were noted between samples with the biological preparation containing T. harzianum T-22 and the control during the study on degradation of a persistent herbicide like pendimethalin. For pendimethalin, the biological preparation extended the dissipation half-life by 12.3 days $(27.3 \%)$ (experiment 1 ) and 0.3 days $(0.6 \%)$. In the case of propyzamide, which is moderately persistent, its half-life was extended by 4.3 days (12.6\%) (experiment 2 ) and shortened by 12.1 days (22.4\%) (experiment 2) (Table 2). Such inconclusive data imply a need for further research into the behavior of these pesticides in soil.

\section{Materials and Methods}

The characteristics of herbicides tested: its octanol-water partition coefficient, chemical structure and group, HRAC group, mode of action, soil degradation, mobility, laboratory and field half-lives, and possible metabolites in soil are presented in Table 1.

\subsection{Reagents}

The reagents used for analyses of herbicides in soil included acetonitrile $400 \mathrm{~g} / \mathrm{L}$ and acetone of analytical grade (CPAchem, Bulgaria-Frence), petroleum ether for GC (Chempur, Polska), analytical standards of herbicides (Sigma-Aldrich, USA), QuEChERS Extraction Kits (4 g magnesium sulfate, $\mathrm{MgSO}_{4} ; 1 \mathrm{~g}$ sodium chloride, $\mathrm{NaCl} ; 1 \mathrm{~g}$ sodium citrate, $\mathrm{Na}_{3} \mathrm{C}_{6} \mathrm{H}_{5} \mathrm{O}_{7} ; 0.5 \mathrm{~g}$ disodium citrate sesquihydrate, $\mathrm{C}_{12} \mathrm{H}_{18} \mathrm{Na}_{4} \mathrm{O}_{17}$ ), and QuEChERS Dispersive Kits (150 mg of primary and secondary amines PSA and $900 \mathrm{mg}, \mathrm{MgSO}_{4}$ ) (Agilent Technologies, Palo Alto, CA, USA).

\subsection{Soil Samples Preparation}

Two types of soil suitable for vegetable cultivation were tested.

Soil 1 was a horticultural soil recommended for vegetable production. It was very acidic ( $\mathrm{pH}$ 4.6), with a high content of organic carbon (OC) and total nitrogen $(\mathrm{N})$. Soil 2 was a universal peat substrate mixed with perlite, acidic, but with the $\mathrm{pH}$ value slightly higher than in Soil 1. It was highly organic soil with the OC and N content only slightly lower than in Soil 1. Soil 2 had a moderate content of plant available $\mathrm{P}$, while in soil $1 \mathrm{P}$ availability was very high (seven times greater than in Soil 2). Soil parameters: fraction, $\mathrm{pH}$, humus content, total carbon, organic carbon, total nitrogen, assimilable phosphorus, and other elements, were determined in the laboratory of The Institute of Soil Science and Plant Cultivation in (Pulawy, Poland) accredited by The Polish Centre for Accreditation (certificate no AB 339) (Table 3).

The experiments were performed in spring, from 25 March to 30 May, in natural light, when in Poland the average day to night ratio is $15 \mathrm{~h}$ to $9 \mathrm{~h}$, respectively. Total of $400 \mathrm{~g}$ samples of soil were weighted into transparent propylene containers of $2 \mathrm{~L}$ each. The biological fungicide TRIANUM-G (Koppert BV, The Netherlands) [21] containing T. harzianum Rifai T-22 was added to one-half of all soil samples at a concentration of $750 \mathrm{~g} / \mathrm{L} \mathrm{m}^{3}$ and mixed, as recommended in the instruction of the commercial product. On the next day, the soil samples were sprayed with $80 \mathrm{~mL}$ of commercial herbicides prepared at the highest doses recommended in their labels [22] (Table 4). 
Table 4. Recommended application, based on the labels [22].

\begin{tabular}{cccccc}
\hline $\begin{array}{c}\text { Plant Protection } \\
\text { Product }\end{array}$ & $\begin{array}{c}\text { Active } \\
\text { Substance }\end{array}$ & $\begin{array}{c}\text { Active Substance } \\
\text { Content in } \\
\text { Product }\end{array}$ & $\begin{array}{c}\text { Recommended } \\
\text { Dose }\end{array}$ & $\begin{array}{c}\text { Recommended } \\
\text { Water Volume }\end{array}$ & $\begin{array}{c}\text { Application } \\
\text { Method }\end{array}$ \\
\hline Command 480 EC & clomazone & $480 \mathrm{~g} / \mathrm{L}$ & $0.2 \mathrm{~L} / \mathrm{ha}$ & $200-300 \mathrm{~L} / \mathrm{ha}$ & \\
Aurelit 70 WG & metribuzin & $700 \mathrm{~g} / \mathrm{kg}$ & $0.5 \mathrm{~kg} / \mathrm{ha}$ & $200-300 \mathrm{~L} / \mathrm{ha}$ & spray \\
Stomp Aqua 455 CS & $\begin{array}{c}\text { pendimethalin } \\
\text { fluazifop-P-butyl }\end{array}$ & $\begin{array}{c}455 \mathrm{~g} / \mathrm{L} \\
150 \mathrm{~g} / \mathrm{L}\end{array}$ & $25 \mathrm{~mL} / 100 \mathrm{~m}^{2}$ & $2-4 \mathrm{~L} / 100 \mathrm{~m} \mathbf{m}^{2}$ & \\
Fusilade Forte 150 EC & $\begin{array}{c}\text { propyzamide } \\
\text { Kerb 50 WP }\end{array}$ & $500 \mathrm{~g} / \mathrm{kg}$ & $1-1.5 \mathrm{~kg} / \mathrm{ha}$ & $\begin{array}{c}100-400 \mathrm{~L} / \mathrm{ha} \\
300-400 \mathrm{~L}\end{array}$ & mixing with \\
Trianum-G & T. harzianum & $10 \mathrm{~g} / \mathrm{kg}$ & $750 \mathrm{~g} / 1 \mathrm{~m}^{3}$ of soil & - & soil \\
\hline
\end{tabular}

Herbicides: Clomazone (Command 480 EC, FMC Chemical, Belgium-1 mL for $1 \mathrm{~L}$ of water), metribuzin (Aurelit $70 \mathrm{WG}$, ADAMA Deutschland GmbH, Germany-2.5 g for $1 \mathrm{~L}$ of water), pendimethalin (Stomp Aqua 455 CS, BASF SE, Germany-12.5 mL for $1 \mathrm{~L}$ of water), fluazifop-P-butyl (Fusilade Forte 150 EC, Syngenta Polska Sp. z o.o., Poland-17 mL for $1 \mathrm{~L}$ of water), and propyzamide (Kerb 50 WP, Dow AgroSciences Polska Sp. z o.o., Poland $-5 \mathrm{~g}$ for $1 \mathrm{~L}$ of water) were applied. Each pesticide was applied separately. The samples were prepared and analyzed in three replicates (three containers for each sample). Propylene containers were closed with a cover one day after chemical spraying and were opened to take samples for GC analysis. The samples for the pesticide analysis were taken after 1, 8, 15, 22, 29, 43, and 64 days. Before sampling, each soil was mixed thoroughly with a laboratory spoon. In each sample, the water content was measured by a weighing method after drying at $105^{\circ} \mathrm{C}(\mathrm{S}-40$, Alpina, Poland) [41]. The moisture of soil samples was in the range of $57-64 \%$. The pesticide concentration was calculated for the soil dry mass. All soil samples were stored in stable laboratory conditions. Throughout the experiments, the air temperature was maintained at $22 \pm 1{ }^{\circ} \mathrm{C}$.

\subsection{GC- $\mu E C D$ Analysis of Herbicide Residues}

The analysis of herbicides in soil was done using a modified method based on the European Norm and literature on the QuEChERS method for soil analysis, involving sample extraction with acetonitrile and clean-up through a dispersive solid phase extraction (d-SPE) [42-45]. Total of $5 \mathrm{~g}$ of soil were weighted into $50-\mathrm{mL}$ polypropylene centrifuge tube, and $20 \mathrm{~mL}$ of acetonitrile $400 \mathrm{~g} / \mathrm{L}$ (acetonitrile:water 1:1 $v / v$ ) were added, hand shaken for $1 \mathrm{~min}$ to hydrate the sample and allowed to stand for $10 \mathrm{~min}$. The tube content was vortexed (BenchMixer ${ }^{\mathrm{TM}}$, Benchmark, Edison, NY, USA) for 1 min. Then, a mixture of salts containing $4 \mathrm{~g} \mathrm{MgSO}_{4} ; 1 \mathrm{~g} \mathrm{NaCl} ; 1 \mathrm{~g} \mathrm{Na}_{3} \mathrm{C}_{6} \mathrm{H}_{5} \mathrm{O}_{7}$, and $0.5 \mathrm{~g} \mathrm{C}_{12} \mathrm{H}_{18} \mathrm{Na}_{4} \mathrm{O}_{17}$ was added. The tube content was vortexed in a mixer (BenchMixer ${ }^{\mathrm{TM}}$, Benchmark, Edison, NY, USA) for $1 \mathrm{~min}$ and then centrifuged at $3000 \mathrm{rpm}$ (MPW-350R, MPW MED. INSTRUMENTS, Warszawa, Poland) for $5 \mathrm{~min}$. Total of $5 \mathrm{~mL}$ of the organic phase were transferred to a $15-\mathrm{mL}$ polypropylene centrifuge tube that contained sorbent for clean-up, consisting of $150 \mathrm{mg}$ of PSA and $900 \mathrm{mg} \mathrm{MgSO}$. The tube content was vortexed in the mixer (BenchMixer ${ }^{\mathrm{TM}}$, Benchmark, Edison, NY, USA) for 1 min and centrifuged at $3000 \mathrm{rpm}$ (MPW-350R, MPW MED. INSTRUMENTS, Warszawa, Poland) for $5 \mathrm{~min}$. Total of $1 \mathrm{~mL}$ of purified extract was transferred to a $2-\mathrm{mL}$ chromatographic vial, acetonitrile extract was evaporated to dryness under a gentle stream of pure nitrogen and then dissolved in $1 \mathrm{~mL}$ of petroleum ether. Each sample was analyzed in three replicates.

A 7890A gas chromatograph (Agilent Technologies, Palo Alto, CA, USA) equipped with a capillary column (HP-5 MS Ultra Inert/30 $\mathrm{m} \times 0.25 \mathrm{~mm}$ I.D. $\times 0.25-\mu \mathrm{m})$ and a micro electron capture detector (GC- $\mu \mathrm{ECD})$ was used to analyze the herbicide residues in soil extracts. The following chromatographic parameters were used: injection of samples in a splitless mode, injected volume $-2 \mu \mathrm{L}$, carrier gas-helium (5.0 purity, flow of $1.37 \mathrm{~mL} / \mathrm{min}$ ), and the temperatures of $250{ }^{\circ} \mathrm{C}$ for the inlet, $300{ }^{\circ} \mathrm{C}$ for the detector, and $100-220{ }^{\circ} \mathrm{C}$ for the oven. Software ChemStation (Rev. B04.03-SP2, Agilent Technologies, Palo Alto, CA, USA) was used for acquisition and processing of the analysis results. 


\subsection{Confirmatory GC-MS Analysis of Pesticides and Possible Metabolites}

A 7890A gas chromatograph (Agilent Technologies, Palo Alto, CA, USA) equipped with a mass detector, model 7000 (GC-MS/MS QqQ), was used to confirm the herbicide residues in soil extracts and search for possible metabolites. The following analysis parameters were used: injection of samples in a splitless mode, injected volume-1 $1 \mu \mathrm{L}$, carrier gas-helium (5.0 purity, flow $1 \mathrm{~mL} / \mathrm{min})$, ionization mode-electron $(-70 \mathrm{eV})$, and the temperatures of $250{ }^{\circ} \mathrm{C}$ for the transfer line, $230{ }^{\circ} \mathrm{C}$ for the ion source, $150{ }^{\circ} \mathrm{C}$ for the quadrupoles, and $40-260^{\circ} \mathrm{C}$ for the oven. Software Mass Hunter, version B.07.06 was used for acquisition and processing of the analysis results. Ions were monitored in the full scan mode. Spectra were compared to spectra obtained for analytical standards of herbicides and to NIST database.

\subsection{Method Validation}

The validation was performed according to the EU guideline SANTE [46]. The parameters of linearity (expressed as a coefficient of determination $\mathrm{R}^{2}$ ), trueness and precision (expressed as an average recovery and a relative standard deviation, RSD), matrix effects, and a limit of quantification (LOQ) were assessed. The materials for validation were soil samples without herbicide residues.

Validation parameters for all active substances in two types of soil met the EU criteria for pesticide analyses described in SANTE documents [46]. Detailed characteristics are given in Table 5. For the herbicide tested, a slight matrix effect was found, ranging from -1 to $11 \%$, except for fluazifop-P-butyl, where it amounted to $-42 \%$ in soil 1 and $-28 \%$ in soil 2 . Therefore, all analyses were performed with reference to the standard mixture prepared in the "blank" matrix.

Table 5. Validation parameters for herbicide active substances in two kind of soils (GC- $\mu$ ECD).

\begin{tabular}{|c|c|c|c|c|c|}
\hline \multirow[t]{2}{*}{$\begin{array}{c}\text { Active } \\
\text { Substance }\end{array}$} & \multirow[t]{2}{*}{$\begin{array}{l}\text { Linearity } \\
\qquad\left(\mathbf{R}^{2}\right)^{1}\end{array}$} & \multicolumn{2}{|c|}{$\begin{array}{c}\text { Average Recovery } \\
\left( \pm \text { RSD }^{2}\right) \\
(\%)\end{array}$} & \multicolumn{2}{|c|}{$\begin{array}{c}\text { Matrix Effects } \\
\left( \pm \text { RSD }^{2}\right) \\
(\%)\end{array}$} \\
\hline & & Soil 1 & Soil 2 & Soil 1 & Soil 2 \\
\hline Clomazone & 0.995 & $81(6)$ & $73(2)$ & 5 & -1 \\
\hline Fluazifop-P-butyl & 0.990 & $84(3)$ & $80(16)$ & -42 & -28 \\
\hline Metribuzin & 0.997 & $120(7)$ & $119(10)$ & 10 & 11 \\
\hline Pendimethalin & 0.999 & $114(5)$ & $119(7)$ & 5 & 2 \\
\hline Propyzamide & 0.999 & $120(5)$ & $107(9)$ & 4 & 9 \\
\hline
\end{tabular}

\subsection{Statistical Analysis of Results}

The Tukey test (program Statistica version 7) was used to determine statistically significant differences between samples, with and without biological preparation added, for each sampling day. Statistically significant $\mathrm{p}$ values are shown in Figures S1-S5, Supplementary material as $p<0.05\left({ }^{*}\right)$ and $p<0.01\left(^{* *}\right)$. No values at a level of $p<0.001\left(^{* * *}\right)$ were determined.

\section{Conclusions}

T. harzianum T-22 influences pesticide degradation and dissipation kinetics for non-persistent herbicides, such as clomazone, fluazifop-P-butyl, and metribuzin. Biological protection of crops can change the concentration of these active substances. On the one hand, this may result in the reduced effectiveness of herbicide treatments, while on the other hand, it can become a tool for achieving the cleaner environment. During the degradation study, no significant differences were noted for pendimethalin which is more persistent. Many other factors can influence the pesticide biodegradation, so further detailed studies should be undertaken in this area. 
Supplementary Materials: Supplementary materials can be found online. Figure S1. Plots of clomazone dissipations, A-experiment 1, B-experiment 2. Statistically significant $p$ values are shown as $p<0.05\left(^{*}\right)$ and $p$ $\left.<0.01{ }^{* *}\right)$. Figure S2. Plots of fluazifop-P-butyl dissipations, A-experiment 1, B-experiment 2. Statistically significant $p$ values are shown as $p<0.05\left(^{*}\right)$ and $p<0.01\left(^{* *}\right)$. Initial values of fluazifop-P-butyl are provided in plots. Figure S3. Plots of metribuzin dissipations, A-experiment 1, B-experiment 2. Statistically significant $p$ value is shown as $p<0.05\left(^{*}\right)$. Figure S4. Plots of pendimethalin dissipations, A-experiment $1, \mathrm{~B}-$ experiment 2. Figure S5. Plots of propyzamide dissipations, A-experiment 1, B-experiment 2. Statistically significant $p$ values are shown as $p<0.05\left(^{*}\right)$ and $p<0.01\left(^{* *}\right)$.

Author Contributions: Conceptualization, E.S.; methodology, E.S.; formal analysis, E.S., A.Z., M.P., M.S.-B., B.P.; G.S.; writing-original draft, E.S.; project administration, E.S.; funding acquisition, E.S. All authors have read and agreed to the published version of the manuscript.

Funding: This research was funded by The National Science Centre, Poland. Grant number-Registration number 2018/02/X/NZ9/00490 Miniatura 2. The effect of a microbiological agent containing Trichoderma Harzianum Rifai strain T-22 on the decomposition of active substances of chemical plant protection products.

Acknowledgments: We would like to thank Edyta Marut, Joanna Piórkowska, and Karolina Zielińska for their support in the laboratory work.

Conflicts of Interest: The authors declare that they have no conflict of interest. The funders had no role in the design of the study; in the collection, analyses, or interpretation of data; in the writing of the manuscript, or in the decision to publish the results.

\section{References}

1. Podbielska, M.; Szpyrka, E.; Matyaszek, A.; Słowik-Borowiec, M.; Rupar, J.; Kurdziel, A. Occurrence and estimation of pesticide residues in edible minor crops in southeastern Poland in 2013-2014. Environ. Monit Assess. 2016, 188, 386. [CrossRef]

2. López-Pacheco, I.Y.; Silva-Núñez, A.; Salinas-Salazar, C.; Arévalo-Gallegos, A.; Lizarazo-Holguin, L.A.; Barceló, D.; Iqbal, H.M.N.; Parra-Saldívar, R. Anthropogenic contaminants of high concern: Existence in water resources and their adverse effects. Sci Total Environ. 2019, 690, 1068-1088. [CrossRef] [PubMed]

3. Damalas, C.A.; Koutroubas, S.D. Current status and recent developments in biopesticide use. Agriculture (Basel) 2018, 8, 13. [CrossRef]

4. Matyjaszczyk, E. Products containing microorganisms as a tool in integrated pest management and the rules of their market placement in the European Union. Pest. Manag Sci. 2015, 71, 1201-1206. [CrossRef] [PubMed]

5. Martyniuk, S. Factors affecting the use of microbial biopesticides in plant protection. Prog Plant. Prot. 2012, 52, 957-962.

6. Tahri Joutey, N.; Bahafid, W.; Sayel, H.; El Ghachtouli, N. Biodegradation: Involved Microorganisms and Genetically Engineered Microorganisms. Biodegradation; Life of Science: London, UK, 2013; Chapter 11, Intech Open; pp. 289-320. ISBN 978-953-51-1154-2. Available online: https://www.intechopen.com/books/biodegradation-life-of-science/biodegradationinvolved-microorganisms-and-genetically-engineered-microorganisms (accessed on 8 January 2020). [CrossRef]

7. Huang, Y.; Xiao, L.; Li, F.; Xiao, M.; Lin, D.; Long, X.; Wu, Z. Microbial Degradation of Pesticide Residues and an Emphasis on the Degradation of Cypermethrin and 3-phenoxy Benzoic Acid: A Review. Molecules 2018, 23, 2313. [CrossRef]

8. Wołejko, E.; Łozowicka, B.; Kaczyński, P.; Jankowska, M.; Piekut, J. The influence of effective microorganisms (EM) and yeast on the degradation of strobilurins and carboxamides in leafy vegetables monitored by LC-MS/MS and health risk assessment. Environ. Monit Assess. 2016, 188, 64. [CrossRef]

9. Schuster, A.; Schmoll, M. Biology and biotechnology of Trichoderma. Appl. Microbiol. Biotechnol. 2010, 87, 787-799. [CrossRef]

10. Dinesh, R.; Prateeksha, M. A review on interactions of Trichoderma with Plant and Pathogens. Res. J. Agric. For. Sci. 2015, 3, 20-23. Available online: http://www.isca.in/AGRI_FORESTRY/Archive/v3/i2/5.ISCA-RJAFS2014-062.pdf (accessed on 10 January 2020).

11. Fraceto, L.F.; Maruyama, C.R.; Guilger, M.; Mishra, S.; Keswani, C.; Singh, H.B.; de Lima, R. Trichoderma harzianum-based novel formulations: Potential applications for management of Next-Gen agricultural challenges. J. Chem. Technol. Biotechnol. 2018, 93, 2056-2063. [CrossRef] 
12. Patil, K.C.; Matsumura, F.; Boush, G.M. Degradation of endrin, aldrin, and DDT by soil microorganisms. J. App Microbiol. 1970, 19, 879-881. [CrossRef]

13. Katayama, A.; Matsumura, F. Degradation of Organochlorine Pesticides, Particularly Endosulfan, by Trichoderma Harzianum. Environ. Toxicol. Chem. 1993, 12, 1059-1065. [CrossRef]

14. Senthilkumar, S.; Anthonisamy, A.; Arunkumar, S.; Sivakumari, V. Biodegradation of Methyl Parathion and Endosulfan Using Pseudomonas Aeruginosa and Trichoderma Viridae. J. Environ. Sci. Eng. 2011, 53, 115-122. [PubMed]

15. Jayaraman, P.; Naveen Kumar, T.; Maheswaran, P.; Sagadevan, E.; Arumugam, P. In vitro Studies on Biodegradation of Chlorpyrifos by Trichoderma viride and T. harzianum. J. Pure Appl. Microbiol. 2012, 6, 1465-1474.

16. Harish, R.; Supreeth, M.; Chauhan, J.B. Biodegradation of organophosphate pesticide by soil fungi. Adv. Bio Tech. 2013, 12, 4-8.

17. Baarschers, W.H.; Heitland, H.S. Biodegradation of fenitrothion and fenitrooxon by the fungus Trichoderma viride. J. Agric. Food Chem. 1986, 34, 707-709. [CrossRef]

18. Sharma, P.; Sharma, M.; Manokaran, R.; Singh, D.V.; Srivastava, M. Use of Trichoderma spp. in biodegradation of carbendazim. Indian J. Agric. Sci. 2016, 86, 891-894.

19. EU Database. EU Pesticides Database; Directorate-General for Health and Food Safety European Commission: Brussels, Belgium, 2020; Available online: https://ec.europa.eu/food/plant/pesticides/eu-pesticides-database/ public/?event=homepage\&language $=\mathrm{EN}$ (accessed on 9 August 2019).

20. BPDB 2019. Bio-Pesticides DataBase; University of Hertfordshire: Hatfield, UK, 2019; Available online: https://sitem.herts.ac.uk/aeru/bpdb/index.htm (accessed on 9 August 2019).

21. Koppert BV. TRIANUM-G label; Koppert BV: Berkel en Rodenrijs, The Netherlands, 2017. Available online: https://www.gov.pl/documents/912055/913531/Trianum-G.pdf/12509ee2-50e0-df1b-9c07d535ac82ca63? version=1.0 (accessed on 11 July 2019).

22. Ministry of Agriculture and Rural Development. Labels of Plant Protection Products; Ministry of Agriculture and Rural Development: Warsaw, Poland, 2018. Available online: https://www.gov.pl/web/rolnictwo/ etykiety-srodkow-ochrony-roslin (accessed on 12 November 2018).

23. PubChem. U.S. National Library of Medicine National Center for Biotechnology Information. 2019. Available online: https://pubchem.ncbi.nlm.nih.gov (accessed on 11 July 2019).

24. PPDB 2019. Pesticide Properties Database; University of Hertfordshire: Hatfield, UK, 2019; Available online: https://sitem.herts.ac.uk/aeru/ppdb/en/ (accessed on 27 July 2019).

25. Wołejko, E.; Kaczyński, P.; Łozowicka, B.; Wydro, U.; Borusiewicz, A.; Hrynko, I.; Konecki, R.; Snarska, K.; Dec, D.; Malinowski, P. Dissipation of S-metolachlor in plant and soil and effect on enzymatic activities. Environ. Monit Assess. 2017, 189, 355. [CrossRef]

26. EFSA. Conclusion regarding the peer review of the pesticide risk assessment of the active substance metribuzin. European Food Safety Authority (EFSA). EFSA J. 2006, 88, 1-74. [CrossRef]

27. Kah, M.; Beulke, S.; Brown, C.D. Factors influencing degradation of pesticides in soil. J. Agric. Food Chem. 2007, 55, 4487-4492. [CrossRef]

28. Van Scoy, A.R.; Tjeerdema, R.S. Environmental fate and toxicology of clomazone. Rev. Environ. Contam Toxicol. 2014, 229, 35-49. [CrossRef]

29. Zanella, R.; Primel, E.G.; Gonçalves, F.F.; Martins, M.L.; Adaime, M.B.; Marchesan, E.; Machado, S.L.O. Study of the degradation of the herbicide clomazone in distilled and in irrigated rice field waters using HPLC-DAD and GC-MS. J. Braz. Chem. Soc. 2008, 19, 987-995. [CrossRef]

30. Tomco, P.L.; Holstege, D.M.; Zou, W.; Tjeerdema, R.S. Microbial degradation of clomazone under simulated California rice field conditions. J. Agric. Food Chem. 2010, 58, 3674-3680. [CrossRef] [PubMed]

31. Men, Y.; Achermann, S.; Helbling, D.E.; Johnson, D.R.; Fenner, K. Relative contribution of ammonia oxidizing bacteria and other members of nitrifying activated sludge communities to micropollutant biotransformation. Water Res. 2017, 109, 217-226. [CrossRef] [PubMed]

32. Reis, M.R.; Leão, E.U.; Santos, G.R.; Sarmento-Brum, R.B.C.; Gonçalves, C.G.; Cardon, C.H.; Silva, D.B. Impact of herbicides on strains of Trichoderma spp. Planta Daninha. 2013, 31, 419-426. [CrossRef]

33. Pelagio-Flores, R.; Esparza-Reynoso, S.; Garnica-Vergara, A.; López-Bucio, J.; Herrera-Estrella, A. Trichoderma-Induced Acidification Is an Early Trigger for Changes in Arabidopsis Root Growth and Determines Fungal Phytostimulation. Front. Plant. Sci. 2017, 8, 1-13. [CrossRef] 
34. Durkin, P.R. Scoping/Screening Level Risk Assessment on Fluazifop-P-butyl; Syracuse Environmental Research Associates Inc.: New York, NY, USA, 2013; p. 293. Available online: https://www.fs.fed.us/foresthealth/ pesticide/pdfs/Fluazifop-P-butyl.pdf (accessed on 7 July 2019).

35. Wahla, A.Q.; Iqbal, S.; Anwar, S.; Firdous, S.; Mueller, J.A. Optimizing the metribuzin degrading potential of a novel bacterial consortium based on Taguchi design of experiment. J. Hazard. Mater. 2018, 15, 1-9. [CrossRef]

36. Nowara, A.M.; Radwan, M.A. Impact of pesticides on Trichoderma harzianum and on its possible antagonistic activity against Fusarium oxysporum under In vitro conditions. Asian J. Agric. Biol. 2017, 5, 291-302.

37. Bordjiba, O.; Steiman, R.; Kadri, M.; Semadi, A.; Guiraud, P. Removal of herbicides from liquid media by fungi isolated from a contaminated soil. J. Environ. Qual. 2001, 30, 418-426. [CrossRef]

38. Kočárek, M.; Artikov, H.; Voříšek, K.; Borůvka, L. Pendimethalin degradation in soil and its interaction with soil microorganisms. Soil Water Res. 2016, 11, 213-219. [CrossRef]

39. Barrere, C.; Bastide, J.; Coste, C.M. Relations entre la vitesse de dégradation du propyzamide et les propriétés physicochimiques des sols. Weed Res. 2006, 28, 93-99. [CrossRef]

40. Matsumura, F.; Boush, G.M. Degradation of insecticides by a soil fungi Trichoderma viride. J. Econ. Entomol. 1968, 61, 610-612. [CrossRef] [PubMed]

41. PN-ISO 11465:1999. Wersja Polska. Jakość Gleby-Oznaczanie Zawartości Suchej Masy Gleby i Wody w Glebie w Przeliczeniu na sucha Masę Gleby_Metoda Wagowa; The Polish Committee for Standardization: Warsaw, Poland, 1999; pp. 1-7.

42. PN-EN 15662:2018. Foods of Plant Origin-Multimethod for the Determination of Pesticide Residues Using GCand LC-based Analysis Following Acetonitrile Extraction/Partitioning and Clean-up by Dispersive SPE-Modular QuEChERS-method; Polski Komitet Normalizacyjny: Warszawa, Poland, 2018; p. 82.

43. Łozowicka, B.; Rutkowska, E.; Jankowska, M. Influence of QuEChERS modifications on recovery and matrix effect during the multi-residue pesticide analysis in soil by GC/MS/MS and GC/ECD/NPD. Environ. Sci. Pollut. Res. 2017, 24, 7124-7138. [CrossRef] [PubMed]

44. Đurović-Pejčev, R.D.; Bursić, V.P.; Zeremski, T.M. Comparison of QuEChERS with Traditional Sample Preparation Methods in the Determination of Multiclass Pesticides in Soil. J. AOAC Int. 2018, 102, 46-51. [CrossRef]

45. Pszczolińska, K.; Michel, M. The QuEChERS Approach for the determination of pesticide residues in soil samples: An Overview. J. AOAC Int. 2016, 99, 1403-1414. [CrossRef]

46. SANTE 2017. Document SANTE/11813/2017. Guidance Document on Analytical Quality Control and Method Validation Procedures for Pesticides Residues Analysis in Food and Feed; Manufacturers: Brussels, Belgium, 2017; p. 46. Available online: https://ec.europa.eu/food/sites/food/files/plant/docs/pesticides_mrl_guidelines_ wrkdoc_2017-11813.pdf (accessed on 5 April 2019).

Sample Availability: Samples of the soil are not available from the authors.

(C) 2020 by the authors. Licensee MDPI, Basel, Switzerland. This article is an open access article distributed under the terms and conditions of the Creative Commons Attribution (CC BY) license (http://creativecommons.org/licenses/by/4.0/). 